УДК 316.4; 336.132

DOI https://doi.org/10.32837/apfs.v0i27.932

Т. Г. Червінська

ORCID ID: https://orcid.org/0000-0001-5054-0206 кандидат соиіологічних наук, доцент, доцент кафедри теорії та історії соиіології Київського національного університету ілені Тараса Шевченка

Ю. В. Петленко
ORCID ID: https://orcid.org/0000-0001-5984-5145
кандидат економічних наук, доцент,
доцент кафедри фінансів
Київського національного університету імені Тараса Шевченка

\title{
ПРОБЛЕМИ ТА ВИКЛИКИ ДИСТАНЦЙНОГО НАВЧАННЯ У ВИЩЙ ОСВІТІ УКРАЇНИ ПІД ЧАС ПАНДЕМІЇ COVID-19
}

Постановка проблеми. Пандемія COVID-19 вплинула на різні сфери суспільного та індивідуального життя, адже змінюються форми та формати нашої роботи, навчання, відпочинку та дозвілля, повсякденні рутинні практики. Необхідність пристосовуватися до нової реальності стимулюють трансформації й вищій освіті. У всьому світі вищі навчальні заклади вимушені переходити на дистанційне навчання, скасовувати, відтерміновувати або обмежувати міжнародну академічну мобільність, розширювати віртуальні формати комунікації та співпраці, шукати нові можливості фінансування. Такі стрімкі й непередбачувані зміни створюють для суб'єктів освітнього процесу численні виклики, які можуть розглядатися в категоріях як загроз, так і нових можливостей та переваг. Все це потребує глибокого аналізу, теоретичного обгрунтування та конкретних емпіричних досліджень.

Аналіз останніх досліджень і публікацій. Дослідження викликів, з якими зіткнулася вища освіта під час пандемії COVID-19, вже здійснюються Міжнародною асоціацією університетів (IAU), Європейською асоціацією університетів (EUA), Європейською асоціацією міжнародної освіти (EAIE) [6-8]. Так, результати першого Глобального опитування Міжнародної асоціації університетів [6] свідчать про те, що пандемія COVID-19 вплинула на викладання та навчання майже в усіх вищих навчальних закладах світу, зокрема у двох третинах з них повідомили, що відбулася заміна аудиторного дистанційним навчанням та викладанням. Такий перехід супроводжувався різноманітними проблемами, до вирішення яких виявилися неготовими більшість ЗВО. Основні труднощі, з якими зіткнулися навчальні заклади, пов'язані з відсутністю технічної інфраструктури та засобів, необхідних для організації дистанційного навчання; складнощами адаптації до онлайн-викладання педагогічного персоналу; обмеженнями дистанційного навчання в певних галузях навчання. Пандемія COVID-19 вплинула на міжнародну співпрацю, скоротивши фізичну та одночасно збільшивши віртуальну академічну мобільність студентства та викладацтва. Багато респондентів назвали фінансові наслідки найважливішим викликом для своїх навчальних закладів. Якщо в приватних установах занепокоєні передусім потенційним дефіцитом доходів через падіння кількості студентства та зменшенням плати за навчання, то державні ЗВО стурбовані можливим зменшенням державної підтримки внаслідок фінансової кризи.

Результати Глобального опитування водночас засвідчують, що вимушений перехід на дистанційне викладання та навчання створюе нові продуктивні можливості для освітян, серед яких слід назвати опанування та випробування нових інструментів та засобів, що забезпечують дистанційний навчальний процес, більшу гнучкість навчання, зростання інновацій у педагогіці викладання, розширення можливостей викладання та навчання на відстані та отримання доступу до можливостей навчання впродовж життя.

В Україні також з'являється все більше досліджень впливу пандемії COVID-19 на різні сфери суспільного життя, зокрема економіку [1] соціальний захист [3], життедіяльність української молоді [5], становище та потреби жінок [4], шкільну освіту [2]. Водночас поки відсутні ґрунтовні дослідження наслідків пандемії COVID-19 для системи вищої освіти в Україні. Заповнення таких лакун вимагає спеціальних наукових досліджень для кращого розуміння викликів, які постали перед закладами вищої освіти України під впливом пандемії COVID-19, та реагування на них.

Отже, метою статті є з'ясування основних проблем, викликів та можливостей переходу на дистанційне навчання закладів вищої освіти в Україні у зв'язку з пандемією COVID-19. 
Виклад основного матеріалу. Для 3’ясування системи викликів, з якими зіштовхнулися заклади вищої освіти України в умовах пандемії COVID-19, та порівняння їх із даними міжнародних асоціацій університетів, дослідницькою групою проєкту НФДУ «Фінансова стабілізація класичних університетів в умовах прояву глобальних наслідків пандемії COVID-19» ${ }^{1}$ в листопаді-грудні 2020 року було проведено онлайн-опитування викладацтва та студентства закладів вищої освіти України.

Більшість респондентів - 91,9\% студентів та 75,8\% викладачів - повідомила про перехід їх навчальних закладів виключно на дистанційне навчання у зв'язку із запровадженням адаптивного карантину в Україні. Цей вимушений перехід супроводжувався низкою проблем та труднощів. Так, лише близько $20 \%$ опитаних студентів $(18,8 \%$ ) та викладачів $(20,8 \%)$ вказали на відсутність будьяких проблем у зв'язку з переходом навчального процесу в онлайн-режим. Усі інші відзначили численні труднощі та перешкоди, котрі його супроводжували (рис. 1). «Рейтинг» проблем як у викладацтва, так і в студентства очолюють технічні (їх відзначили $42 \%$ викладачів та $40,2 \%$ студентів), наступними є проблеми зміни обсягів навчального навантаження $(32,3 \%$ та $40,1 \%$ відповідно), проблеми, пов'язані з якістю навчання $(33,8 \%$ та $35,7 \%$ відповідно) та організацією навчального процесу дистанційно (31,2\% та $36,2 \%$ відповідно).

Основною проблемою технічного характеру (рис. 2) як студенти (55\% ), так і викладачі (43,5\%) визнали проблеми інтернет-з'єднання, зокрема швидкість Інтернету, слабкість та/або нестійкість сигналу, що ускладнюють повноцінну та якісну участь у дистанційному навчанні. Зрозуміло, що цю проблему зазначені суб'єкти освітнього процесу далеко не завжди спроможні вирішити самостійно, отже, потребують допомоги з боку власних навчальних закладів. Для викладацтва $(35,7 \%)$ також актуальними є проблеми недостатності або відсутності необхідної технічної підтримки їх та студентів, а також якісних технічних засобів для повноцінної участі в онлайн-заняттях (30,9\%), що $€$ достатньо актуальним і для студентства $(22,1 \%)$. 3 одного боку, визнання необхідності технічної підтримки є свідченням неготовності до дистанційного навчання передусім самих викладачів, що проявляється у недостатності знань, умінь та навичок, необхідних для повноцінної організації та участі в онлайн-навчанні. 3 іншого боку, така ситуація актуалізує питання технічної підтримки закладами вищої освіти свого студентства та

Онлайн-опитування проведене в межах проєкту № 2020.01/0256 НФДУ «Фінансова стабілізація класичних університетів в умовах прояву глобальних наслідків пандемії COVID-19" в листопаді-грудні 2020 року. Збір інформаціі відбувався на платформі Limeservey в період з 6 листопада 2020 року по 15 грудня 2020 року. Було отримано 269 завершених відповідей за цільовою групою викладачів та 1023 завершені відповіді за цільовою групою студентів ЗВО України. В опитуванні взяли участь викладачі та студенти ЗВО різних регіонів України (Києва, Харкова, Ужгороду, Одеси, Львову, Чернівців, Дніпра). викладацтва через організацію системи заходів, таких як створення відповідної технічної інфраструктури, організація навчань, консультацій, супроводу та підтримки, яких має вжити навчальний заклад для забезпечення якісного дистанційного навчання. Водночас близько чверті опитаних (23,4\% викладачів та $24,9 \%$ студентів) не стикалися 3 проблемами технічного характеру під час здійснення дистанційного навчання.

І студентство, і викладацтво одностайні у визнанні найважливішою проблемою, котра впливає на якість дистанційного навчання (рис. 3), погіршення рівня засвоєння матеріалу (43\% та $36,4 \%$ відповідно). Окрім цього, опитані студентки та студенти вказують на складність адаптації певних дисциплін та галузей знання до онлайн-формату (43,5\%), а також скаржаться на брак спілкування та уваги викладацтва до їх потреб $(33,9 \%)$. Викладачі ж більш стурбовані ускладненням комунікації (42,8\%) та оцінюванням студентства $(34,6 \%$ ) в режимі онлайн, а також недостатньою адаптованістю навчальних методик до дистанційного навчання (32\%).

Під час порівняння відповідей викладацтва та студентства на запитання про проблеми, котрі вплинули на якість навчання, цікавим видається факт більш критичного ставлення кожної цільової групи респондентів до іншої групи. Так, викладацтво вказує на власну недостатню технічну підготовленість у 16,4\% випадків, більш критично оцінюючи технічну готовність до дистанційного навчання студентства $(26,4 \%)$. Студентство також вище оцінює власну технічну спроможність до дистанційного навчання порівняно з викладачами.

Однією з проблем, яку констатують більшість опитаних викладачів $(72,9 \%)$ та майже половина студентів (48,9\% ), є збільшення навчального навантаження в результаті переходу на дистанційне навчання, що, ймовірно, пов'язане з часовими, фізичними та емоційними витратами. Однією з причин такої ситуації для викладацтва є зростання кількості різних звітних документів у зв'язку з переходом навчання в онлайн-режим, підготовка яких потребує часу, на що скаржаться 57,2\% респондентів. Окрім цього, однією з причин зростання обсягів навантаження викладачів, ймовірно, є додаткові часові витрати для опанування новими інструментами та технологіями, необхідними для продуктивної інтеграції до більш технологічного освітнього середовища. Однією з причин збільшення навчального навантаження студентства, на що вони вказували у фокусованих групових інтерв'ю на етапі підготовки опитувальника, ймовірно, є небажання чи недостатня спроможність викладачів організовувати дистанційне навчання, через що відбувається його заміна завданнями для самостійного опрацювання.

Більшість опитаних $(83,6 \%$ викладачів та $77,9 \%$ студентів) вказала на активність власних закладів вищої освіти щодо забезпечення дистанційного навчання. Йдеться, зокрема, про запуск платформ дистанційного навчання, про наявність яких повідомили 78,4\% опитаних викладачів. 


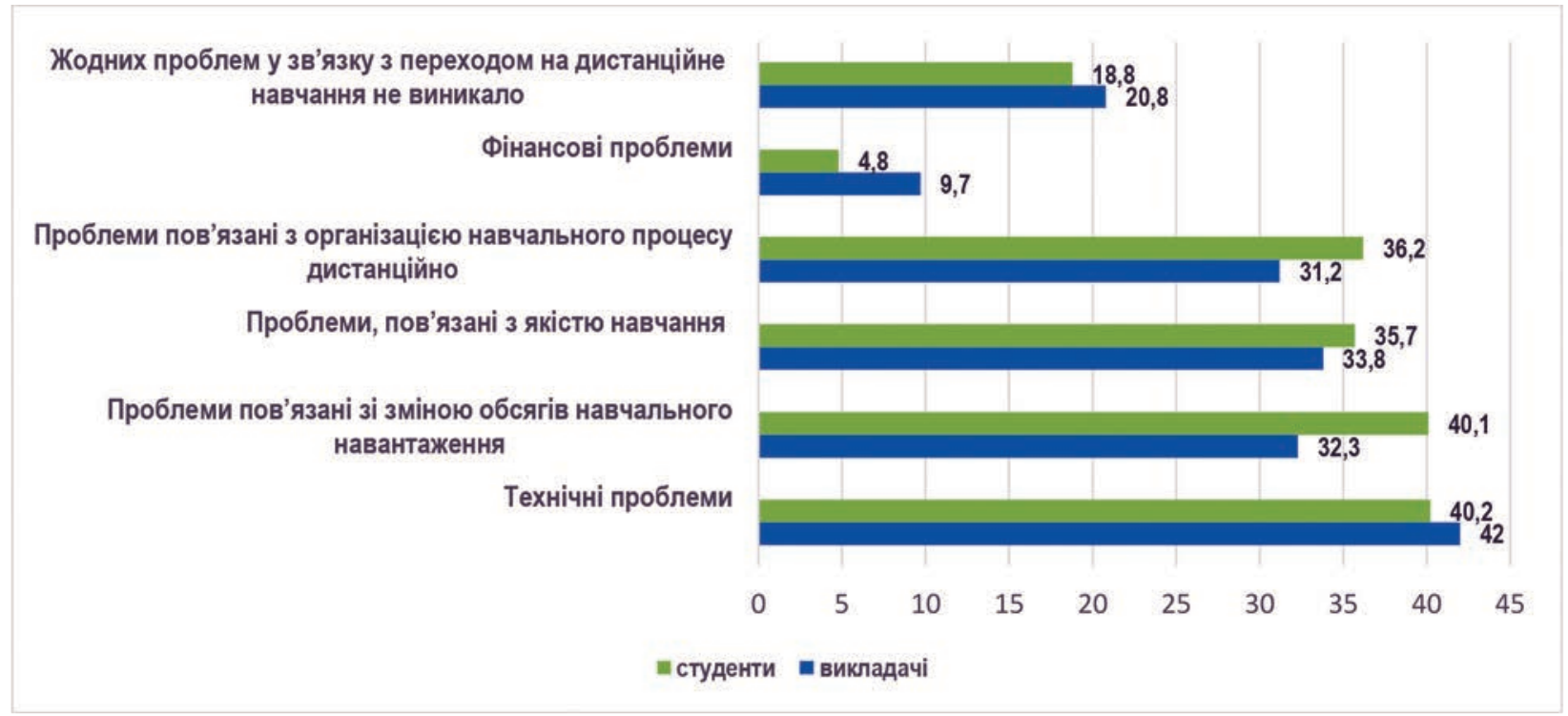

Рис. 1. 3 якими проблемами навчального процесу

Ви зіткнулися у зв'язку з переходом на дистанційне навчання? (\% )

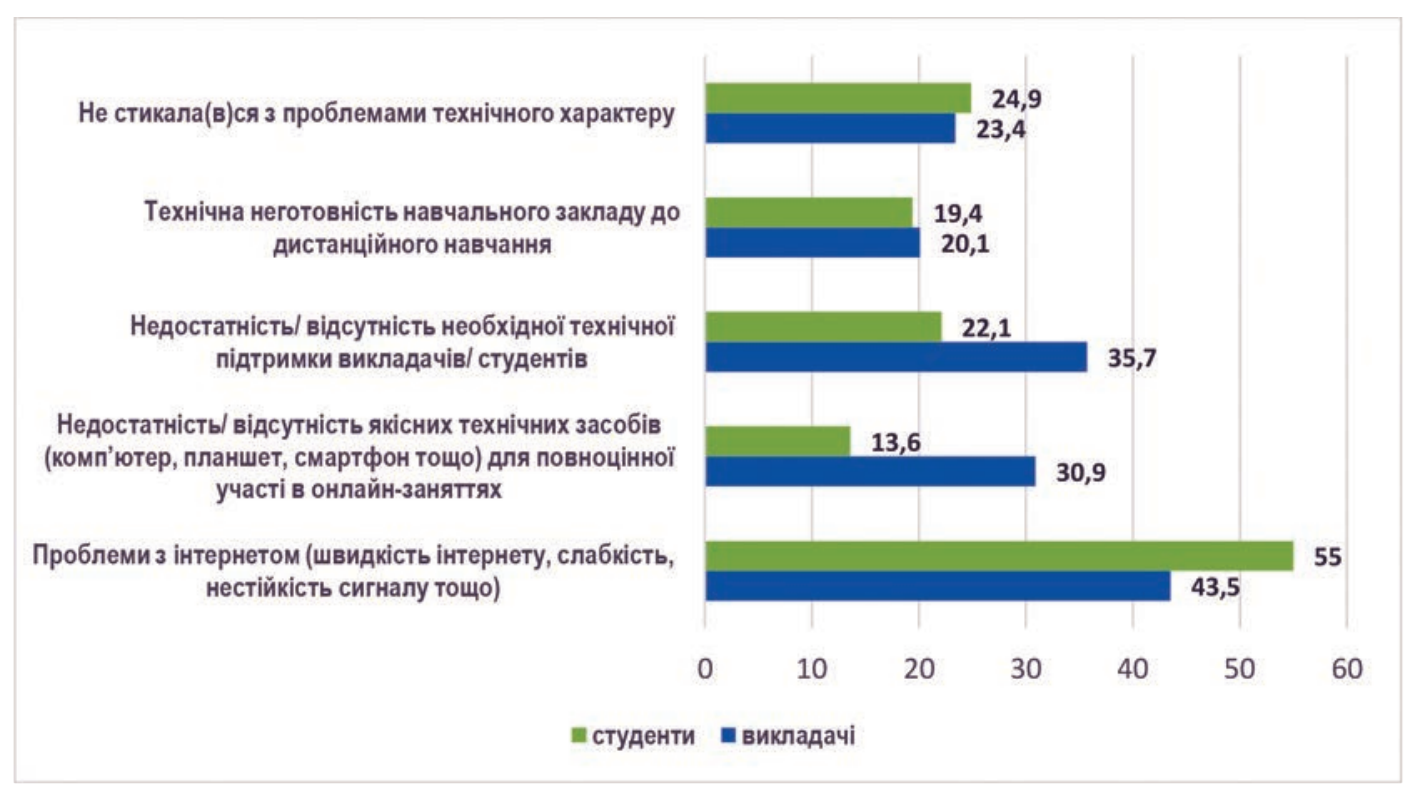

Рис. 2. 3 якими проблемами технічного характеру

Ви зіткнулися у зв'язку з переходом на дистанційне навчання? (\%)

Серед інших заходів, вжитих навчальними закладами, викладачі називали організацію навчання (курсів, тренінгів, вебінарів, семінарів) для викладачів та (рідше) студентів, закупівлю техніки для забезпечення проведення онлайн-занять, укладення договорів та придбання доступу для більш широкого використання інструментів, які пропонують онлайн-платформи (Zoom, Google Meet, Microsoft Office 365 тощо), організаційно-правове та методичне забезпечення процесу дистанційного навчання, постійну підтримку та зворотний зв'язок. Лише 7,8\% викладачів та 5\% студентів відзначили відсутність таких заходів.
Водночас результати опитування показують, що запуск власних дистанційних платформ зовсім не свідчить про їх ефективність та активне використання. Серед платформ, які найчастіше використовуються у дистанційному навчанні (рис. 4), безумовними лідерами і у студентства, i у викладацтва є Zoom (80\% та $66,9 \%$ відповідно) та Google Meet (58,9\% та 47,2\% відповідно). Натомість власна платформа навчального закладу використовується лише 21,9\% опитаних викладачів та $17,8 \%$ студентів, що, ймовірно, вказує або на проблеми в її роботі, або на недостатній функціонал у забезпеченні дистанційного навчання. 


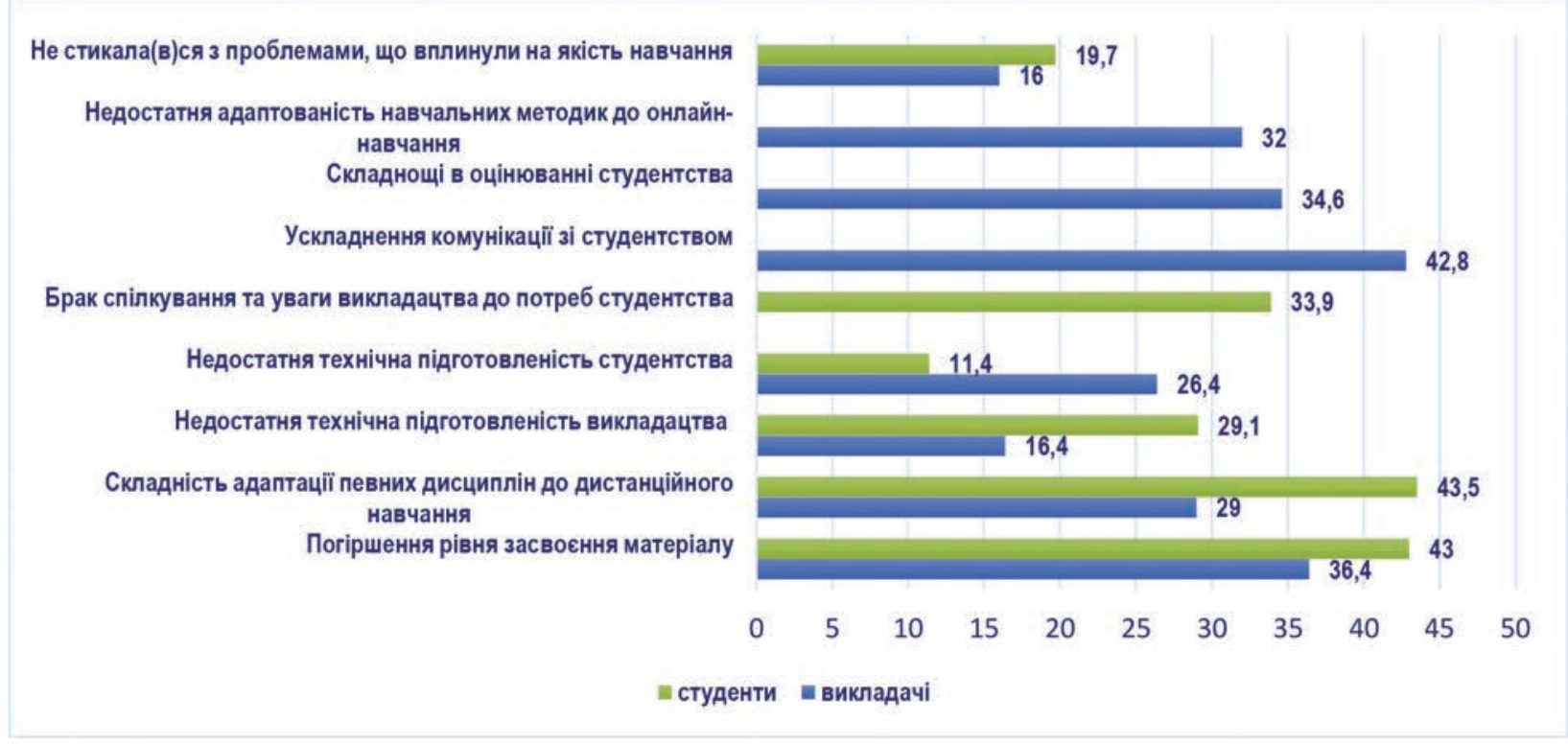

Рис. 3. 3 якими проблемами, що вплинули на якість навчання, Ви зіткнулися у зв'язку з переходом на дистанційне навчання? (\%)

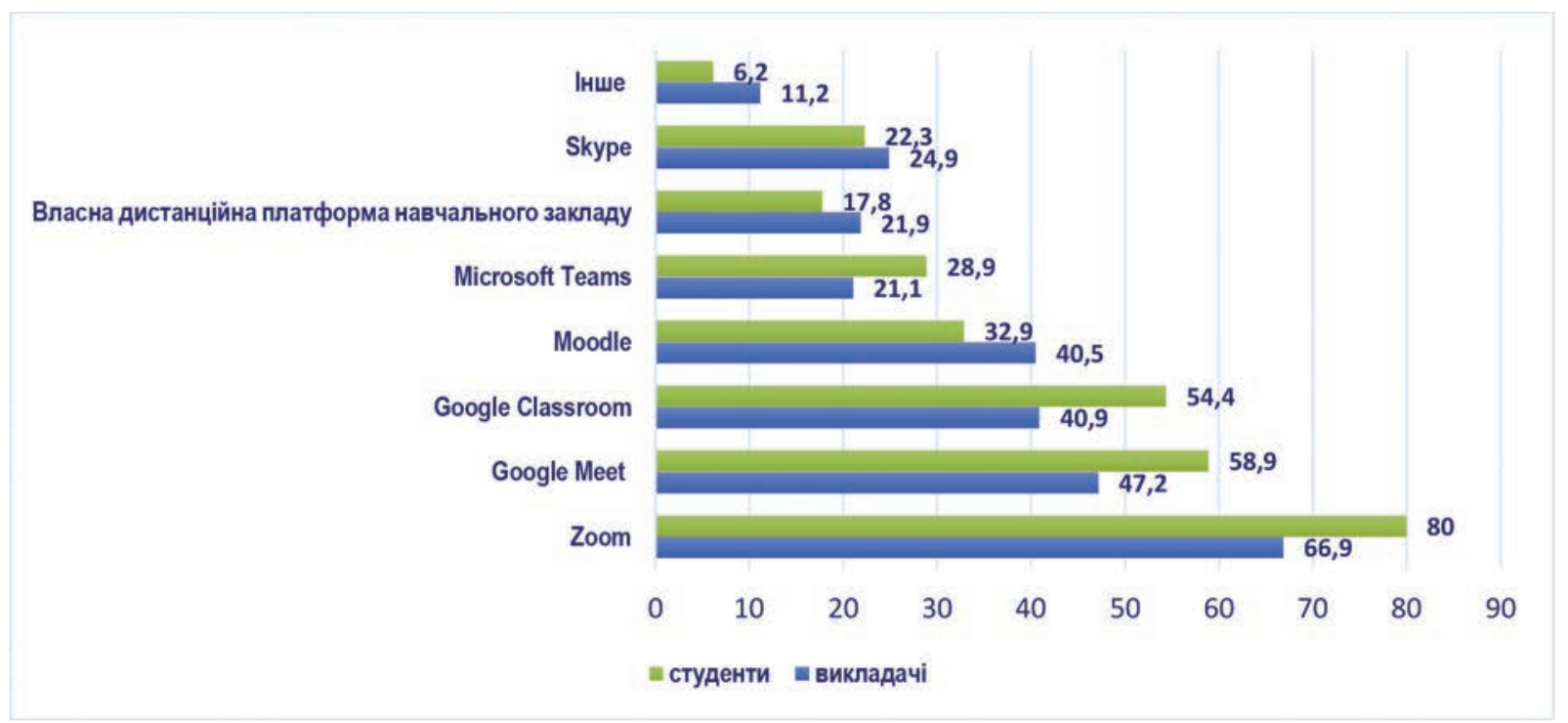

Рис. 4. Які платформи використовуються Вами/у Вашому навчальному закладі для організації дистанційного навчання? (\%)

Оцінки викладачами заходів, вжитих закладами вищої освіти для забезпечення дистанційного навчання, засвідчують вищий порівняно зі студентством рівень задоволеності (74,7\% та $48 \%$ повністю або загалом задоволених відповідно).

Щодо заходів, яких необхідно вжити закладам вищої освіти для вирішення проблем, котрі виникли у зв'язку з переходом на дистанційне навчання, думки студентства та викладацтва мають незначні відмінності (рис. 5). Більше половини опитаних викладачів серед топ-3 проблем, які потребують вирішення, відзначають необхідність укладення вищими навчальними закладами до- говорів з платформами дистанційного навчання $(58,7 \%)$, скорочення кількості документації та звітності, що супроводжують дистанційне навчання $(57,2 \%)$, організацію постійної технічної підтримки учасників навчального процесу $(56,1 \%)$. Пріоритети студентства в перших двох пунктах співпадають з викладацькими, хоча мають нижчий рівень підтримки. Окрім цього, $45,3 \%$ опитаних студентів очікують від своїх ВНЗ здійснення різної підтримки (психологічної, фінансової тощо). Відповіді респондентів обох цільових груп демонструють нижчий рівень технічної готовності викладачів до дистанційного навчання i, відповідно, 


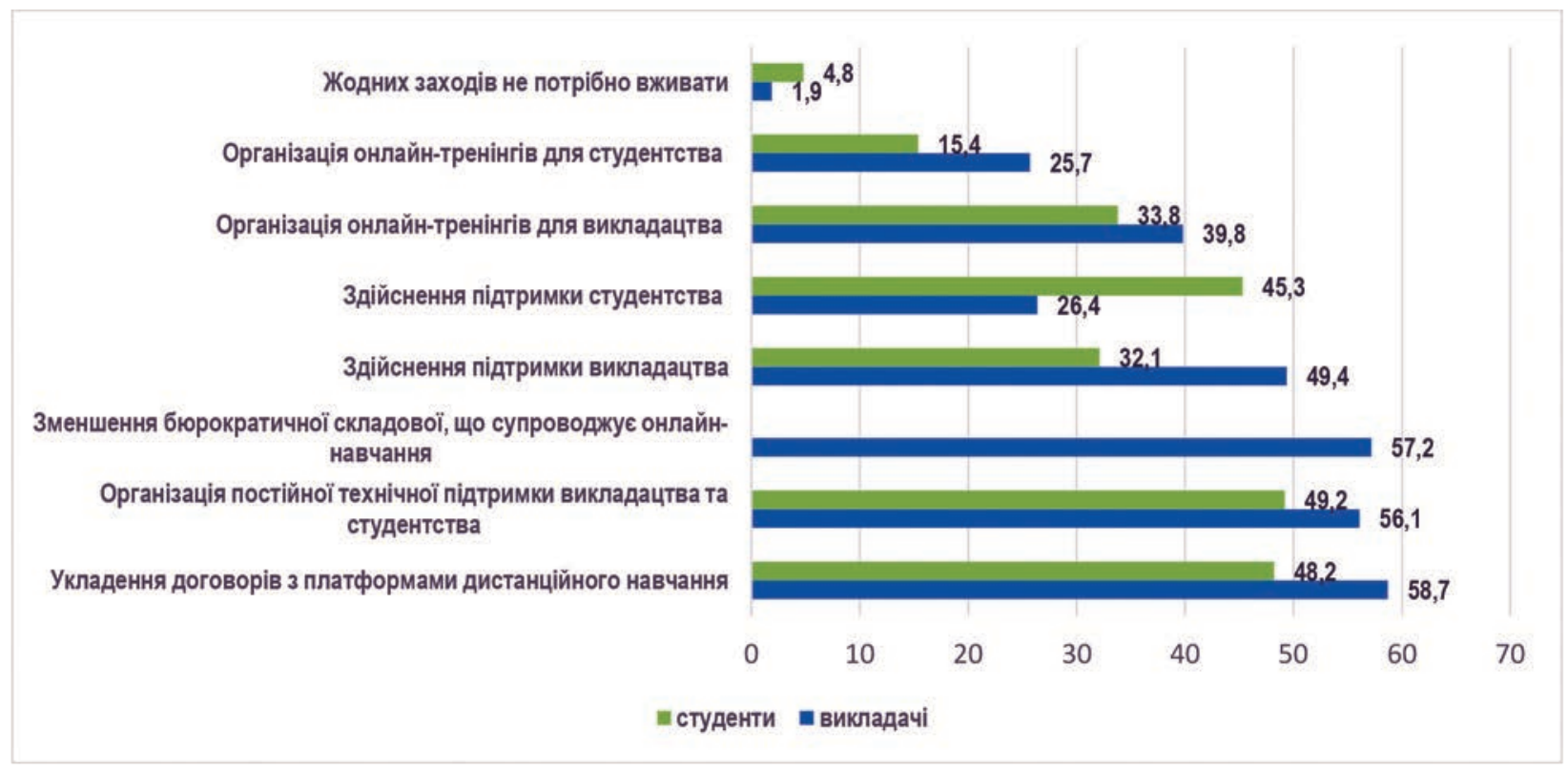

Рис. 5. Яких заходів, на Вашу думку, необхідно вжити вищим навчальним закладам задля вирішення проблем, що виникли у зв'язку з переходом на дистанційне навчання? (\%)

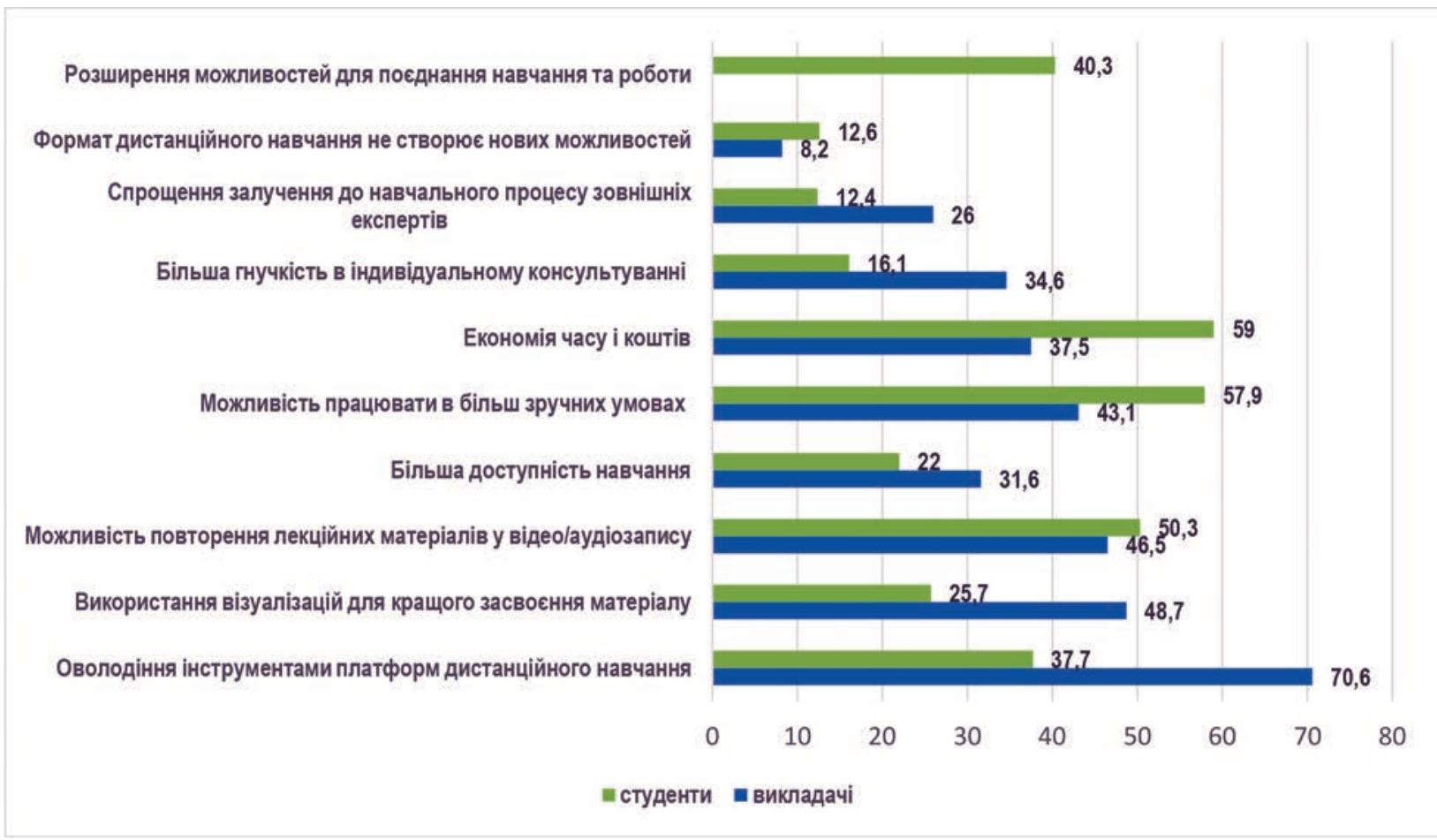

Рис. 6. Які, на вашу думку, можливості та переваги створює формат дистанційного навчання? (\%)

необхідність його підвищення, зазначаючи серед заходів, яких слід вжити ЗВО, організацію онлайн-тренінгів для викладацтва, з чим погоджуються $39,8 \%$ опитаних викладачів та $33,8 \%$ студентів. Натомість очікування організації таких тренінгів для студентства є нижчим, що може свідчити як про вищу оцінку його технічно-інфор- маційної грамотності, так і про визнання ключовими суб'єктами, які організовують дистанційне навчання i, відповідно, мають володіти для цього достатніми компетентностями, саме викладачів.

Оцінка можливостей та переваг, які створює формат дистанційного навчання, у викладацтва та студентства також дещо різниться (рис. 6). 
Серед переваг викладачі передусім відзначають оволодіння новими інструментами, які надають платформи дистанційного навчання $(70,6 \%)$, ширші можливості для використання візуалізацій, що сприяють кращому засвоєнню матеріалу $(48,7 \%)$, можливість повторення лекційних матеріалів у запису $(46,5 \%)$, роботу в більш зручних умовах $(43,1 \%)$. Студентство ж до основних переваг, пов'язаних з дистанційним навчанням, відносить головним чином економію часу та коштів $(59 \%)$, можливість працювати в більш зручних умовах (57,9\%), доступ до відео/аудіозапису лекційних матеріалів $(50,3 \%)$ в будь-який зручний час, що розширює можливості для поєднання навчання та роботи $(40,3 \%)$, що особливо актуалізується в умовах економічної кризи.

Висновки. Пандемія COVID-19, яка вплинула на різні сфери суспільного життя, змусила суб'єктів освітнього процесу - як вищий адміністративний менеджмент, так і викладацтво та студентство - швидко пристосовуватися до змін, які вже давно назріли. Така адаптація, зокрема перехід на дистанційне навчання, виявила низку проблем, вирішення яких як потребує активного залучення самих викладачів та студентів, так і ставить конкретні завдання перед закладами вищої освіти. Проведене дослідження підтверджує, що карантинні обмеження, пов' язані з попередженням проявів глобальної пандемії COVID-19, докорінно змінили умови функціонування ЗВО та зумовили необхідність посилення заходів фінансової стабілізації не тільки в Україні, але й в усьому світі.

Світова пандемія та економічна криза визначають необхідність врахування динамічності процесів, одночасної цифровізації викладання та навчання, підтримки якості освіти і науково-дослідної роботи. Результати дослідження засвідчують, що класичні університети виявилися найбільш підготовленими до переходу на дистанційну та змішану форми навчання. Окремі вищі навчальні заклади мають власні платформи для дистанційного навчання, іншим довелося швидко запроваджувати такі системи, що створило додаткове навантаження на всіх учасників освітнього процесу. Водночас заклади вищої освіти потребують значного фінансування для забезпечення віддаленої роботи за усіма напрямами діяльності.

Складні непередбачувані ситуації і виклики це не лише загрози, але й можливості, а саме можливості переосмислювати, розвиватися, вчитися, шукати нові та вдосконалювати наявні інструменти й засоби викладання і навчання. Розуміння студентством і викладацтвом як проблем, так і можливостей, котрі створює формат дистанційного навчання, допоможе закладам вищої освіти України досягти більшої гнучкості навчання в нових умовах, сприятиме розвитку інноваційних педагогічних методик і стимулюватиме до вжиття заходів, які відповідають викликам сьогодення.

\section{Jimepamypa}

1. Вплив COVID-19 та карантинних обмежень на економіку України. Кабінетне дослідження. Громадська організація «Центр прикладних досліджень». Представництво Фонду Конрада Аденауера в Україні. URL: https://www.kas.de/uk/web/ukraine/ einzeltitel/-/content/vpliv-covid-19-ta-karantinnihobmezen-na-ekonomiku-ukraini.

2. Дослідження стану реалізації дистанційного навчання в Україні (березень-квітень 2020 року). Центр інноваційної освіти «Про.Світ». URL: https://nus.org.ua/wp-content/uploads/2020/05/ Research2020_ProSvit_MF1.pdf?fbclid=IwAR0G4GgjV0Ttb uMIiLHGYAyd_ 79aPuyb7FCwzCmfzgp1KrBCb2t8tkLDCeo.

3. Коронавірус і соціальний захист: між реформою i кризою. Дослідження аналітичного центру CEDOS. URL: https://cedos.org.ua/uk/articles/koronavirus-taosvita-analiz-problem-i-naslidkiv-pandemii.

4. Оперативна гендерна оцінка становища та потреб жінок у контексті ситуації з COVID-19 в Україні. URL: https://www.auc.org.ua/sites/default/ files/report_rga_covid-19_ukr_0.pdf.

5. Як живе молодь України під час COVID-19? URL: https://www.ua.undp.org/content/ukraine/uk/ home/library/democratic_governance/COVID-19impact-on-youth-in-Ukraine.html.

6. IAU Global Survey on the Impact of COVID-19 on Higher Education around the World. URL: https://www. iau-aiu.net/IMG/pdf/iau_covid19_and_he_survey_ report_final_may_2020.pdf.

7. Public Funding Observatory 2020/2021 Part 1: Financial and economic impact of the Covid-19 crisis on universities in Europe. URL: https://eua. eu/resources / publications / 944:public-fundingobservatory-2020-2021.html.

8. Rumbley L. Coping with COVID-19: International higher education in Europe. URL: https://www.eaie.org/ our-resources/library/publication/Research-and-trends/ Coping-with-COVID-19--International-higher-educationin-Europe.html.

\section{Анотація}

Червінська Т. Г., Петленко Ю. В. Проблеми та виклики дистанційного навчання у вищій освіті під час пандемії COVID-19. - Стаття.

У статті розглянуто наслідки пандемії COVID-19 для вищої освіти в Україні та світі. Авторки здійснюють аналіз результатів досліджень Міжнародної асоціації університетів, Європейської асоціації університетів, Європейської асоціації міжнародної освіти, присвячених з'ясуванню впливу пандемії на викладання та навчання, міжнародну академічну мобільність і співпрацю, фінансове становище вищих навчальних закладів; труднощів, загроз та викликів, з якими зіткнулися заклади вищої освіти в усьому світі під час коронакризи і які потребують швидких та адекватних дій. В основній частині статті представлено результати опитування викладачів та студентів закладів вищої освіти України, присвяченого аналізу проблем та викликів, з якими зіткнулися останні під час переходу на дистанційне навчання, а також нових продуктивних можливостей, котрі створює онлайн-формат. До основних проблем, 3 якими зіткнулися основні суб'єкти освітнього 
процесу, належать проблеми якості навчання та організації навчального процесу дистанційно, зростання обсягів навчального навантаження викладачів та студентів, технічні та фінансові проблеми. Результати опитування як засвідчують оцінку та задоволеність заходами, яких уже вживають заклади вищої освіти задля забезпечення якісного та ефективного дистанційного навчання, так і допомагають у розумінні наступних продуктивних кроків, які необхідно зробити для розширення можливостей викладання та навчання на відстані й отримання доступу до можливостей навчання впродовж життя. Оцінка освітянами можливостей та переваг, які створює формат дистанційного навчання, демонструє внутрішню вмотивованість викладачів до вдосконалення власних вмінь та навичок, опанування новими інструментами, яких потребує формат дистанційного навчання; для студентів такими перевагами стають передусім економічні, а саме розширення можливостей для поєднання навчання та роботи, економія часу й коштів.

Ключові слова: пандемія COVID-19, вища освіта, дистанційне викладання та навчання.

\section{Summary}

Chervinska T. G. Petlenko Yu. V. Problems and challenges of distance learning in higher education during the COVID-19 pandemic. - Article.

The article considers the consequences of the COVID-19 pandemic for higher education in Ukraine and the world. The authors analyze the results of research by the International Association of Universities, the European University Association, the European
Association for International Education, to determine the impact of the pandemic on teaching and learning, international academic mobility and cooperation, the financial situation of higher education; difficulties, threats and challenges faced by higher education institutions around the world during the coronary crisis, which require swift and adequate action. The main part of the article presents the results of a survey of teachers and students of higher education institutions of Ukraine, devoted to the analysis of problems and challenges faced by the latter in the transition to distance learning, as well as new productive opportunities created by online format. The main problems faced by the main actors in the educational process include the quality of teaching and organization of the distance learning process, the growth of the workload of teachers and students, technical and financial problems. The results of the survey show both the assessment and satisfaction with the measures already taken by higher education institutions to ensure quality and effective distance learning, and help to understand the next productive steps to be taken to expand teaching and distance learning opportunities and access to learning opportunities during life. Educators' assessment of the opportunities and benefits created by the distance learning format demonstrates the intrinsic motivation of teachers to improve their own skills and abilities, mastering the new tools required by the distance learning format; for students such advantages become first of all economic: expansion of opportunities for a combination of study and work, and also economy of time and means.

Key words: COVID-19 pandemic, higher education, distance teaching and learning. 